\title{
Pembuatan Hand Sanitizer sebagai salah satu upaya pencegahan Covid-19 di Kota Pekanbaru, Indonesia
}

\author{
Arisman Adnan*, Nurhayati, Maria Erna, Ari Sulistyo Rini, \& Ody Azis Saputra \\ Universitas Riau \\ * arisman.adnan@lecturer.unri.ac.id
}

\begin{abstract}
Abstrak. Di awal tahun 2020, dunia dikejutkan dengan merebaknya pneumonia baru yang bermula di Wuhan, Provinsi Hubei yang kemudian menyebar dengan cepat ke lebih dari 190 negara dan wilayah. Wabah ini bernama penyakit coronavirus 2019 (Covid-19) yang disebabkan oleh Severe Acute Respiratory Syndrome Coronavirus-2 (SARS-CoV2). Salah satu cara penularan virus ini adalah melalui tangan yang terkontaminasi bakteri dan virus selama beraktivitas dan masuk melalui saluran pernafasan. Salah satu cara paling sederhana dan bisa dilakukan untuk mencegah hal tersebut adalah dengan mencuci tangan menggunakan sabun atau antiseptik, hand sanitizer. Mencuci tangan dapat mengurangi jumlah bakteri hingga 58\%. Keunggulan hand sanitizer dapat membunuh kuman dalam waktu yang relatif cepat. Bahan aktif hand sanitizer umumnya adalah senyawa golongan alkohol dengan konsentrasi $\pm 60 \%$ sampai dengan $80 \%$ dan golongan fenol (triclosan) sehingga memiliki mekanisme kerja denaturasi dan koagulasi protein sel kuman. Oleh karena itu, pembuatan hand sanitizer secara sederhana bisa dilakukan sendiri dalam kegiatan pengabdian masyarakat. Kegiatan ini bertujuan untuk memproduksi hand sanitizer sebagai upaya pencegahan penularan Covid-19 dalam kehidupan sehari-hari. Evaluasi kegiatan pelayanan yang akan dilakukan untuk melihat seberapa banyak masyarakat yang sadar akan pentingnya menjaga diri dan lingkungan serta menjaga jarak guna memutus mata rantai penyebaran virus.
\end{abstract}

Kata kunci: covid-19, hand sanitizer, proteksi.

Abstract. In early 2020, the world was shocked by the outbreak of new pneumonia that started in Wuhan, Hubei Province which then spread rapidly to more than 190 countries and territories. This outbreak is named coronavirus disease 2019 (Covid-19) which is caused by Severe Acute Respiratory Syndrome Coronavirus-2 (SARS-CoV-2). People are not aware that their hands are often contaminated with bacteria and viruses during their activities. One of the simplest ways and can be done to prevent this is to wash your hands using soap or antiseptic, hand sanitizer. Washing your hands can reduce the number of bacteria by up to 58\%. The advantages of hand sanitizers can kill germs in a relatively fast time. The active ingredients of hand sanitizers are generally alcohol group compounds with a concentration of $\pm 60 \%$ to $80 \%$ and the phenol group (triclosan) so that they have a mechanism of action by denaturing and coagulating cell protein germs. Therefore, making hand sanitizers in simple stages can be done alone in community service activities. This service aims to find out how high public awareness is in dealing with the Covid-19 outbreak in everyday life. Evaluation of the service activities that will be carried out is to see how many people are aware of the importance of protecting themselves and the environment and maintaining distance in order to break the chain of spreading the virus.

Keywords: covid-19, hand sanitizers, protecting.

To cite this article: Adnan, A., Nurhayati., M. Erna., A. S. Rini., \& O. A. Saputra. 2020. Pembuatan Hand Sanitizer sebagai salah satu upaya pencegahan Covid-19 di Kota Pekanbaru, Indonesia. Unri Conference Series: Community Engagement 2: 325-328. https://doi.org/10.31258/unricsce.2.325-328

(C) 2020 Authors

Peer-review under responsibility of the organizing committee of Seminar Nasional Pemberdayaan Masyarakat 2020 


\section{PENDAHULUAN}

Coronavirus adalah keluarga besar virus yang menimbulkan penyakit mulai dari gejala ringan sampai berat. Dua jenis coronavirus diketahui menyebabkan penyakit yang dapat menimbulkan gejala berat yaitu Middle East Respiratory Syndrome (MERS) dan Severe Acute Respiratory Syndrome (SARS). Coronavirus Disease 2019 (Covid-19) adalah penyakit jenis baru yang belum teridentifikasi sebelumnya pada manusia. Virus penyebab Covid-19 ini diberi nama Sars-CoV-2. Virus corona adalah zoonosis (dapat ditularkan antara manusia dan hewan). Peneliti menyebutkan bahwa SARS ditransmisikan dari kucing luwak (civet cats) ke manusia sedangkan untuk virus dari unta ke manusia disebut MERS. Gejala dan tanda umum terinfeksi Covid19 antara lain gejala gangguan pernapasan akut seperti sesak napas, batuk dan demam.

Studi meta-analisis yang dilakukan oleh Yang, dkk. (2020) menunjukkan bahwa pasien Covid-19 dengan riwayat penyakit sistem respirasi akan cenderung memiliki manifestasi klinis yang lebih parah. Gejala ringan didefinisikan sebagai pasien dengan infeksi akut saluran napas atas tanpa komplikasi, bisa disertai dengan demam, fatigue, batuk (dengan atau tanpa sputum), anoreksia, malaise, nyeri tenggorokan, kongesti nasal, atau sakit kepala. Pasien tidak membutuhkan suplementasi oksigen. Pada beberapa kasus pasien juga mengeluhkan diare dan muntah. Mencuci tangan adalah salah satu tindakan sanitasi dengan membersihkan tangan dan jari jemari dengan menggunakan air ataupun cairan lainnya oleh manusia dengan tujuan untuk menjadi bersih dan terhindar dari penyebaran virus tersebut. saat tidak dicuci dengan sabun dapat memindahkan bakteri, virus, dan parasit pada orang lain yang tidak sadar bahwa dirinya sedang ditularkan (Susilo, A. et al., 2019).

Salah satu pintu masuknya kuman kedalam tubuh adalah melalui tangan. Data WHO menunjukkan, tangan mengandung bakteri sebanyak 39.000 hingga $460.000 \mathrm{CFU} / \mathrm{cm} 2$ 7. Dalam kehidupan sehari hari sering kali tangan terkontaminasi dengan mikroba ataupun virus yang bentuknya sangat kecil, sehingga tangan bisa saja menjadi perantara masuknya bakteri maupun virus kedalam tubuh. Memelihara kebersihan tangan merupakan salah satu cara untuk menjaga kesehatan tubuh. Infeksi dari berbagai penyakit, sebagian besar terjadi akibat kemalasan dalam menjaga kebersihan tangan. Salah satu upaya untuk mencegah terjadinya infeksi melalui tangan yaitu dengan pemakaian antiseptik sebagai pengganti sabun dan air yang dinilai tidak praktis dalam pemakaiannya. Mencuci tangan dapat menurunkan jumlah bakteri sampai dengan 58\% (Nurahmanto, et al. 2018).

Salah satu bentuk teknologi modern produk antiseptik yaitu hand sanitizer. Hand Sanitizer memiliki kelebihan dibandingkan hand wash, yang terutama yaitu dalam segi kepraktisannya. Hand Sanitizer yang dibuat dalam bentuk spray. mudah dibawa kemana-mana, dengan daya bunuh kuman yang efektif serta tidak menyebabkan kelengketan dibandingkan dengan handsanitizer dalam bentuk gel (Martono \& Suharyani, 2018). Menghadapi wabah Covid-19 dalam melakukan proteksi dasar WHO memberi anjuran untuk melakukan cuci tangan baik melakukan sabun dan air atau menggunakan cairan berbahan dasar alkohol. Perilaku mencuci tangan ini merupakan hal yang harus selalu diterapkan. Namun, pada keadaan tertentu cuci tangan merupakan suatu hal yang merumitkan dan tidak praktis. Alkohol menjadi salah satu opsi yang tepat untuk mendesinfeksi tangan sebagai pintu masuknya virus ke dalam tubuh. Alkohol yang dijadikan bahan dasar dalam pembuatan handsanitizer merupakan salah satu anjuran WHO untuk digunakan. Hand Sanitizer yang mudah dikemas dan mudah dibawa kemana-mana adalah hal tepat sebagai pencegahan penularan Covid19 (Golin, et al 2020; Singhal, 2020).

Tempat-tempat yang berpotensi tinggi terkena covid-19 adalah tempat-tempat umum dan tempat yang banyak didatangi oleh khalayak ramai seperti masjid, mushalla, puskesmas, kantor lurah. Ada beberapa kecamatan di Pekanbaru yang nantinya akan menjadi tempat pendistribusian hand sanitizer diantaranya Kecamatan Tampan, Rumbai, Marpoyan Damai, Sukajadi, dan Sail. Kecamatan tersebut merupakan kecamatan yang pernah terkonfirmasi positif covid-19 sehingga tempat tersebut adalah tempat yang sangat relevan sebagai tempat pendistribusian hand sanitizer di kota Pekanbaru.

\section{METODE PENERAPAN}

Kegiatan ini dilakukan di Laboratorium Kimia Anorganik Universitas Riau pada bulan Maret-Juli 2020. Tahap pelaksanaan penelitian meliputi persiapan alat dan bahan, pembuatan hand sanitizer, dan dengan menggunakan analisis deskriptif kualitatif, kuantitatif serta tahapan akhir hingga distribusi. 


\section{a. Alat dan Bahan}

Alat-alat yang dipergunakan untuk membuat hand sanitizer yaitu gelas ukur (pyrex) $1000 \mathrm{~mL}$, gelas ukur (pyrex) $100 \mathrm{~mL}$, gelas beker (pyrex) $2000 \mathrm{~mL}$, batang pengaduk, corong kaca (pyrex). Bahan-bahan yang digunakan untuk membuat hand sanitizer alcohol 96\%, gliserol, hidrogen peroksida $\left(\mathrm{H}_{2} \mathrm{O}_{2}\right) 3 \%$, aquades $\left(\mathrm{H}_{2} \mathrm{O}\right)$.

\section{b. Prosedur Pembuatan Hand Sanitizer}

Pembuatan hand sanitizer 1 Liter sebagai berikut:

Alkohol 96\% sebanyak $833 \mathrm{ml}$ dimasukkan ke dalam beaker glass $1000 \mathrm{~mL}$, Hidrogen Peroksida $\left(\mathrm{H}_{2} \mathrm{O}_{2}\right) 3 \%$ sebanyak 41,7 mL ditambahkan ke dalam beaker glass $1000 \mathrm{~mL}$, Gliserol sebanyak 14,5 mL ditambahkan ke dalam beaker glass $1000 \mathrm{~mL}$, Aquades ditambahkan hingga larutan tepat $1000 \mathrm{~mL}$. Selanjutnya campuran diaduk hingga homogen dan dipindahkan ke dalam botol kecil, simpan selama 3×24 jam, dan hand sanitizer siap digunakan.

c. Tahapan Pendistribusian

Selanjutnya, setelah tahap pembuatan hand sanitizer dengan berbagai volume dibuat, hand sanitizer tersebut dimasukkan kedalam botol-botol spray dan diberi label. Kemudian dikemas kedalam kardus dan bisa langsung didistribusikan ke tempat tempat pelayanan masyarakat seperti mesjid, klinik, puskesmas dan kantor lurah terdekat.

\section{HASIL DAN KETERCAPAIAN SASARAN}

Adapun kegiatan pembuatan hand sanitizer ini bertujuan untuk mempermudah masyarakat dalam mematuhi protokol kesehatan karena dinilai lebih praktis daripada mencuci tangan memakai sabun. Kelebihan dari hand sanitizer yaitu dapat membunuh kuman relatif cepat karena adanya kandungan alkohol konsentrasi 60\%-80\%, sehingga mekanisme kerja dengan cara mendenaturasi dan mengkoagulasi protein pada kuman lebih cepat. Kegiatan ini merupakan salah satu program kerja dari Satgas UNRI yang dilakukan dalam taraf sederhana laboratorium Kimia Anorganik Jurusan Kimia FMIPA Universitas Riau.

Pembuatan hand sanitizer dalam bentuk spray juga dinilai lebih mudah untuk diaplikasikan dan tidak membutuhkan waktu pembuatan yang lama. Pembuatan handsanitizer dalam bentuk spray ini juga dapat dilakukan di rumah dengan ketentuan volume dan bahan tertentu seperti lidah buaya. Dalam melakukan kegiatan ini, diharapkan dapat membantu meningkatkan kesadaran masyarakat terhadap protokol kesehatan, dimana pentingnya selalu mencuci tangan dan memakai hand sanitizer dimanapun kita berada. Dengan adanya kegiatan ini, dapat pula membantu pemerintah dalam mendistribusikan perlindungan terhadap pandemi covid19. Kegiatan ini juga disambut baik oleh masyarakat setempat, sehingga mereka tidak perlu mengeluarkan biaya lebih untuk penggunaan hand sanitizer tersebut.

\section{KESIMPULAN}

Covid-19 adalah penyakit baru yang telah menjadi pandemi. Penyakit ini harus diwaspadai karena penularan yang relatif cepat, memiliki tingkat mortalitas yang tidak dapat diabaikan, dan belum adanya terapi definitif. Masih banyak knowledge gap dalam bidang ini sehingga diperlukan studi-studi lebih lanjut. Oleh sebab itu diperlukan kesadaran masyarakat terhadap pentingnya selalu menjaga kesehatan dimulai dari seringnya mencuci tangan atau memakai hand sanitizer. Mencuci tangan dapat menurunkan jumlah bakteri sampai dengan 58\%. Masyarakat sering menggunakan gel antiseptik sebagai media pencuci tangan (hand sanitizer) untuk menggantikan sabun dan air agar lebih praktis. Pemakaiannya yang efektif dan efisien menjadi daya tarik utama dari hand sanitizer. Selama proses pembuatan hand sanitizer yang dilakukan didapatkan beberapa kendala yaitu terhambatnya proses pembuatan dikarenakan bahan yang belum tersedia di lab sehingga memakan waktu untuk menunggu bahan-bahan yang telah dipesan tersebut. Hand sanitizer yang dibuat dalam bentuk spray mudah dibawa kemana-mana, dengan daya bunuh kuman yang efektif serta tidak menyebabkan kelengketan dibandingkan dengan hand sanitizer dalam bentuk gel.

\section{UCAPAN TERIMA KASIH}

Kami mengucapkan terimakasih kepada berbagai pihak yang telah membiayai projek ini terutama ditujukan kepada Lembaga Pengabdian kepada Masyarakat (LPPM) UNRI, Wakil Rektor II UNRI yang mendanai kegiatan awal projek ini dan dilanjutkan oleh Wakil Rektor III UNRI melalui dana kemahasiswaan. 


\section{DAFTAR PUSTAKA}

Al-Tawfiw, J.A., R. Abdrabalnabi, A.Taher, S. Mathew. K.A. Rahman. 2019. "Infection Control influence of Middle East Respiratory Syndrome Coronavirus: A Hospital-Based Analysis”. Am J Infect Control, 47(4), 431-434.

Golin, A. P., D. Choi, \& A. Ghahary. 2020. "Hand Sanitizers: A Review of Ingredients, Mechanisms of Action, Modes of Delivery, and Efficacy Against Coronaviruses". AJIC: American Journal of Infection Control, 48(9), 10621067. https://doi.org/10.1016/j.ajic.2020.06.182

Martono, C., \& I. Suharyani. 2018. Formulasi sediaan Spray Gel antiseptik dari ekstrak etanol lidah buaya (Aloe Vera). Jurnal Farmasi. 3(1), 29-37.

Nurahmanto, D., E. Tanjaya, H. E. Arizka, S. U. Hasanah (2019). Perbandingan aktivitas antimikroba ekstrak etanol daun beluntas (Pluchea Indica L) sediaan gel dan spray antiseptik. Jurnal Prosiding Seminar Nasional Current Challenges in Drug Use and Development Tantangan Terkini Perkembangan Obat dan Aplikasi Klinis 6. Fakultas Farmasi, Universitas Jember.

Singhal, T. 2020. “A Review of Coronavirus Disease-2019 (Covid-19)”. Indian J. Pediatr, 87(4), 281-286.

Susilo, A., C. M. Rumende, C. W. Pitoyo, W. D. Santoso, M. Yulianti, H. Herikurniawan, R. Sinto, G. Singh, L. Nainggolan, E. J. Nelwan, L. K. Chen, A. Widhani, E. Wijaya, B. Wi. 2020. Jurnal Penyakit Dalam Indonesia, $7(1), 45-67$.

Yang J, Y. Zheng, X Gou, K. Pu, Z. Chen, Q. Guo. 2020. Prevalence of comorbidities and its effects in patients infected with SARS-COV-2: a systematic review and meta-analysis. Int J Infect Dis. 